\title{
ANALISA SEA LEVEL ANOMALY MENGGUNAKAN RETRACKING WAVEFORMS DARI DATA SATELIT ALTIMETRI JASON-2 (Studi Kasus : Pesisir Pulau Bali)
}

\author{
Dwipayana Kusumawardhana, Bangun Muljo Sukojo \\ Program Studi Teknik Geomatika FTSP-ITS, Kampus ITS Sukolilo, Surabaya, 60111 \\ Email : dwipayanakusuma@gmail.com, bangunms@gmail.com
}

\begin{abstract}
Abstrak
Sea Level Anomaly (SLA) adalah perubahan sebenarnya dari topografi laut yang berhubungan dengan arus laut. Teknologi satelit altimetri yang sudah dikembangkan sejak tahun 1975 menjadi salah satu alternatif dalam memperoleh informasi tentang dinamika lautan. Salah satu misi dari satelit ini adalah dengan diluncurkannya satelit altimetri Jason-2 pada tahun 2008.

Retracking waveforms merupakan pemodelan kembali bentuk gelombang yang dihantarkan oleh satelit altimetri ke daratan untuk mendapatkan hasil yang lebih baik. Pada dasarnnya satelit altimetri memiliki ketelitian yang baik di lautan lepas, tetapi untuk di daerah pesisir mengalami gangguan dalam penerimaan gelombang di akibatkan oleh ombak, vegetasi dan bentuk pesisir pantai tersebut.

Dari hasil penelitian menunjukkan bahwa proses retracking waveforms di wilayah pesisir Pulau Bali didapatkan nilai SLA tertinggi pada tahun 2011 adalah 1.1242 m pada bulan Desember dan nilai SLA terendahnya adalah -2.0084 m pada bulan yang sama dan untuk proses tanpa retracking waveforms didapatkan nilai SLA tertinggi pada tahun 2011 adalah $1.6436 \mathrm{~m}$ yaitu pada bulan Desember dan nilai SLA terendahnya adalah $-1.5690 \mathrm{~m}$ pada bulan November dan Desember. Dengan melalui proses retracking waveforms didapatkan nilai SLA yang lebih teliti dan akurat dibandingkan tanpa melalui proses retracking waveforms terlebih dahulu.
\end{abstract}

Kata Kunci : Jason-2, Pesisir, Sea Level Anomaly, Waveforms

\section{PENDAHULUAN}

\section{Latar Belakang}

Bali adalah nama salah satu propinsi di Indonesia dan juga merupakan nama pulau yang menjadi bagian dari propinsi tersebut. Pulau Bali terletak di $8^{\circ} 3^{\prime} 40^{\prime \prime}$ - $8^{\circ} 50^{\prime} 48^{\prime \prime}$ Lintang Selatan dan $114^{\circ} 25^{\prime} 53^{\prime \prime}$ - $115^{\circ} 42^{\prime} 40^{\prime \prime}$ Bujur Timur. Wilayah pesisir Pulau Bali rentan terhadap efek kenaikan permukaan air laut karena perubahan iklim yang disebabkan oleh pemanasan global dan karena Pulau Bali merupakan pulau wisata, kemungkinan akan berdampak negatif langsung dari fenomena naiknya permukaan air laut sehingga akan mempertinggi abrasi pantai, erosi garis pantai, penggenangan wilayah daratan, meningkatnya frekuensi dan intensitas banjir, meningkatnya dampak badai di daerah pesisir, salinisasi lapisan aquifer dan kerusakan ekosistem wilayah pesisir, merusak permukiman, tambak, daerah pertanian, dan lain-lain di kawasan pantai.
Teknologi satelit altimetri yang sudah dikembangkan sejak tahun 1975 menjadi salah satu alternatif dalam memperoleh informasi tentang dinamika lautan. Salah satu misi dari satelit ini adalah dengan diluncurkannya satelit altimetri Jason-2 pada tahun 2008. Data satelit ini didistribusikan dengan media CD-ROM untuk keperluan penelitian diseluruh dunia yang disebut Merged Geophyisical Data Record (MGDR) (AVISO dan PODAAC 2008).

Salah satu obyek penelitian satelit Jason-2 adalah untuk mengetahui Sea Level Anomaly dalam suatu wilayah. Salah satu informasi yang terdapat dalam Sea Level Anomaly adalah perubahan sebenarnya dari topografi laut yang berhubungan dengan arus laut. Dengan mengetahui Sea Level Anomaly yang terjadi di wilayah pesisir Pulau Bali tersebut diharapkan mampu mengatasi dampak negatif yang akan terjadi. 
Gelombang micro aktif yang dipancarkan oleh satelit altimetri disebut waveforms dimana berfungsi untuk mengukur jarak tempuh (range) gelombang dari satelit ke permukaan laut. Retracking waveforms dilakukan di wilayah pesisir 0-10 km dari garis pantai (Thibaut, Gómez-Enri dan Deng 2001). Diharapkan dengan melakukan proses retracking waveforms dari data satelit Jason-2 akan didapatkan Sea Level Anomaly yang lebih akurat di wilayah pesisir Pulau Bali.

\section{Rumusan Permasalahan}

Pokok permasalahan yang diangkat dalam penulisan Tugas Akhir ini adalah bagaimana proses dan analisa untuk mendapatkan Sea Level Anomaly di wilayah pesisir Pulau Bali setelah melalui proses retracking waveforms dari data satelit Jason-2.

\section{Batasan Masalah/Ruang Lingkup}

Adapun batasan masalah yang diajukan dalam penelitian ini adalah sebagai berikut:

1. Proses retracking waveforms difokuskan untuk wilayah pesisir Pulau Bali yang dilewati satelit altimetri Jason-2 pada pass 025, 203 dan 216.

2. Penelitian dilakukan menggunakan data satelit altimetri Jason-2 pada cycle 92 sampai cycle 128 selama tahun 2011.

3. Pemrosesan data menggunakan software Matlab 7.8 dan BRAT 3.0.1

\section{Tujuan}

Tujuan penulisan penelitian ini adalah :

1. Mengetahui proses retracking waveforms di wilayah pesisir sehingga didapatkan Sea Level Anomaly.

2. Memahami proses pengolahan data waveforms dari satelit altimetri Jason-2 dengan menggunakan software Matlab 7.8 dan BRAT 3.0.1

3. Menganalisa Sea Level Anomaly di pesisir Pulau Bali setelah dilakukan proses retracking waveforms.

\section{Manfaat}

Adapun manfaat dari penelitian ini adalah mendapatkan informasi tentang Sea Level yang lebih baik dan lebih dini tentang perubahan anomali laut yang terjadi dipesisir pantai yang dapat bermanfaat untuk mendukung program pemerintah seperti mitigasi bencana atau perencanaan wilayah pesisir serta memberikan wawasan mengenai pemrosesan retracking waveforms yang nantinya diharapkan dapat bermanfaat bagi penelitian-penelitian selanjutnya.

\section{METODOLOGI PENELITIAN}

\section{Lokasi Penelitian}

Lokasi penelitian adalah di wilayah pesisir Pulau Bali yang dilewati oleh satelit Jason-2 yaitu pada pass 025, 203, dan 216 pada koordinat 7¹8'18.92" - 9॰31'8.89" LS dan $113^{\circ} 25^{\prime} 55.48^{\prime \prime}$ $116^{\circ} 39^{\prime} 55.13^{\prime \prime}$ BT seperti pada gambar 1.

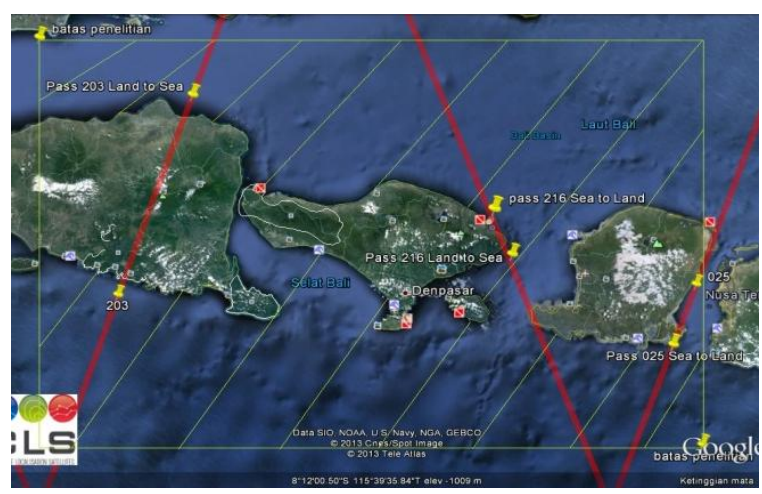

Gambar 1. Lokasi penelitian

\section{Data Dan Peralatan}

- Data

Data yang digunakan dalam penelitian ini adalah:

1. Data waveforms $20 \mathrm{~Hz}$ dari satelit altimetri Jason-2 di pesisir pulau Bali pada pass 025, 203, dan 216 cycle 92 - 128 tahun 2011 dalam format SGDR (Scientific Geophysical Data Records) yang diproduksi oleh PODAAC. Hal ini dikarenakan pada awal tahun 2011 dimulai pada cycle 92 sampai pada cycle 128 pada akhir tahun 2011.

2. Data satelit altimetri Jason-2 pada pass 025, 203, dan 216 cycle 92 - 128 tahun 2011 dalam format GDR (Geophysical Data Records) yang diproduksi oleh AVISO. Data ini digunakan sebagai data pembanding Sea Level Anomaly yang akan dianalisa nantinya. 


\section{- Peralatan}

Peralatan yang digunakan dalam penelitian ini adalah:

1. Perangkat Keras (Hardware)
a. Laptop
b. Printer

2. Perangkat Lunak (Software)
a. MATLAB 7.8.0 2009
b. BRAT 3.0.12009

\section{Diagram Alir Pengolahan Data}

Adapun untuk diagram alir pengolahan data adalah sebagai berikut:

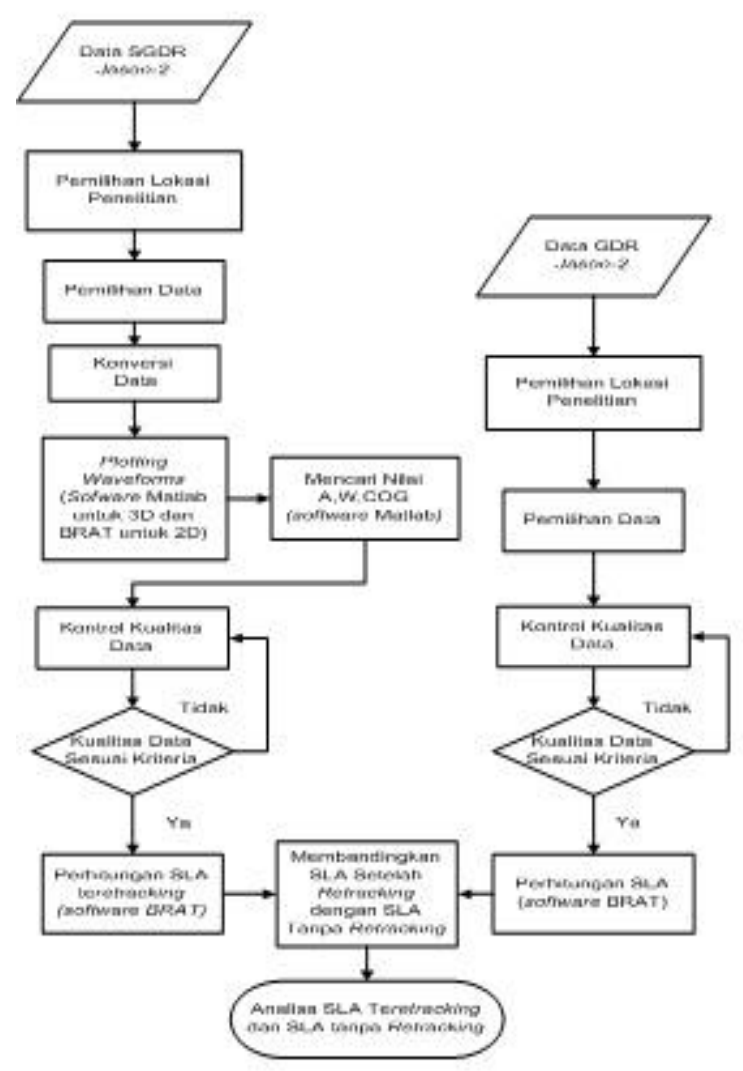

Gambar 2. Diagram Alir Pengolahan Data

Proses pengolahan data pada penelitian ini di mulai dengan pengambilan data SGDR dari satelit Jason-2

1. Pemilihan Lokasi

Pada penilitian ini lokasi yang di ambil pada wilayah pesisir pulau Bali yang dilewati satelit Jason-2 pada pass 025, 203, dan 216.

2. Pemilihan Data

Setelah ditetapkan lokasi penelitiannya, maka selanjutnya dilakukan pemilihan data satelit Jason-2 yang sesuai dengan waktu penelitian yaitu pada cycle 92-128 serta data waveforms $20 \mathrm{~Hz}$.

3. Konversi Data

Konversi data dilakukan untuk mengubah data format biner dari satelit Jason-2 menjadi data format ASCII. Tujuan dari tahap ini adalah untuk mendapatkan parameter-parameter yang dibutuhkan untuk proses plotting waveforms.

4. Plotting Waveforms

Plotting waveforms dilakukan untuk mengetahui bentuk waveforms di daerah penelitian yang akan diretracking.

5. Mencari Nilai A, W, COG.

Pada tahap ini melakukan pehitungan nilai amplitude (A), panjang gelombang (W), Center Of Gravity (COG) pada waveforms.

6. Kontrol Kualitas Data

Kontrol kualitas data digunakan untuk mendapatkan kualitas terbaik. Jika data telah sesuai dengan kriteria maka bisa dilanjutkan pada proses selanjutnya.

7. Perhitungan SLA Teretracking

Setelah mendapatkan nilai waveforms (range) di lakukan perhitungan SLA dimana waveforms teretracking dimasukkan kedalam nilai a (jarak dari antena altimeter satelit ke permukaan laut sesaat).

Setelah mendapatkan SLA teretracking dari data SGDR maka pengolahan data di lanjutkan dari data satelit Jason-2 dengan format GDR

1. Pemilihan Lokasi

Pada penilitian ini lokasi yang di ambil pada wilayah pesisir pulau Bali yang dilewati satelit Jason-2 pada pass 025, 203, dan 216.

2. Pemilihan Data

Setelah ditetapkan lokasi penelitiannya, maka selanjutnya dilakukan pemilihan data satelit Jason-2 yang sesuai dengan waktu penelitian yaitu pada cycle 92-128.

3. Kontrol Kualitas Data

Proses ini sama seperti proses sebelumnya pada data SGDR pada proses ke-6.

4. Perhitungan SLA

Setelah kriteria kualiatas data terpenuhi maka dilanjutkan dengan perhitungan SLA.

5. Membandingkan SLA Setelah Retracking dengan SLA Tanpa Retracking 
Setelah didapatkan SLA yang telah melalui proses retracking waveform dan SLA tanpa proses retracking waveforms, maka dapat dibandingkan pada grafik yang dihasilkan dari pengamatan SLA dari kedua proses tersebut.

6. Analisa SLA Teretracking dan SLA Tanpa Retracking

Hasil dari SLA teretracking dan SLA tanpa retracking di analisis untuk mengetahui hasil SLA mana yang lebih teliti dan baik.

\section{HASIL DAN PEMBAHASAN}

\section{Konversi/Eksport Data}

Data satelit Jason-2 merupakan data dalam bentuk format biner. Tahap konversi data diperlukan untuk mengubah format data biner menjadi format data ASCII (American Standard Code for Information Interchange). Konversi data dilakukan dengan menggunakan software BRAT. Proses konversi data dilakukan agar menghasilkan data ASCII yang memiliki format yang dapat dibaca, sehingga akan lebih mudah untuk mengambil parameter-parameter data yang diperlukan untuk pengolahan data yang dalam kasus ini diperlukan untuk proses plotting waveforms nantinya.

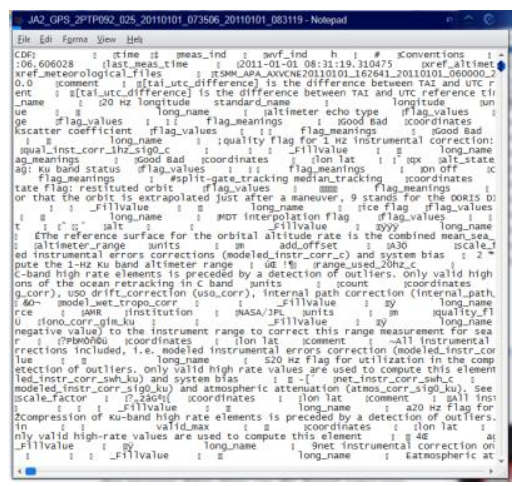

Gambar 3. Data Format Biner Sebelum Dilakukan Proses Konversi/Export Data

Data yang sudah dilakukan konversi data yakni dalam format ASCII adalah sebagai berikut:

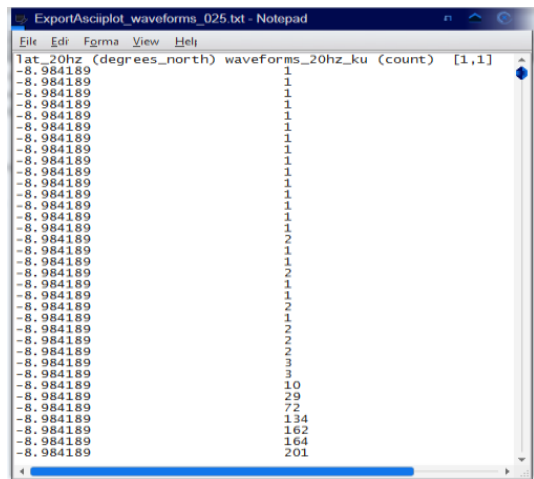

Gambar 4. Data Format ASCII Setelah Dilakukan Proses Konversi Data

Baris yang ada menunjukan banyaknya data yang dihasilkan pada setiap pass, sedangkan kolom berfungsi memisahkan data berdasarkan pada parameter - parameter yang dihasilkan oleh program konversi tersebut.

\section{a. Plotting Waveforms}

Data yang telah dikonversi/diexport ke dalam format ASCII tersebut digunakan untuk pengeplotan yakni pengeplotan waveforms pada tiap pass selama tahun 2011. Plot waveforms tersebut berbentuk grafik tiga dimensi dan dua dimensi, dengan tujuan memudahkan untuk melihat hasil pengeplotan yang nantinya juga memudahkan untuk mencari nilai range dari tiap waveforms pada data SGDR yang dihasilkan di setiap cycle pada suatu pass yang sedang diteliti.

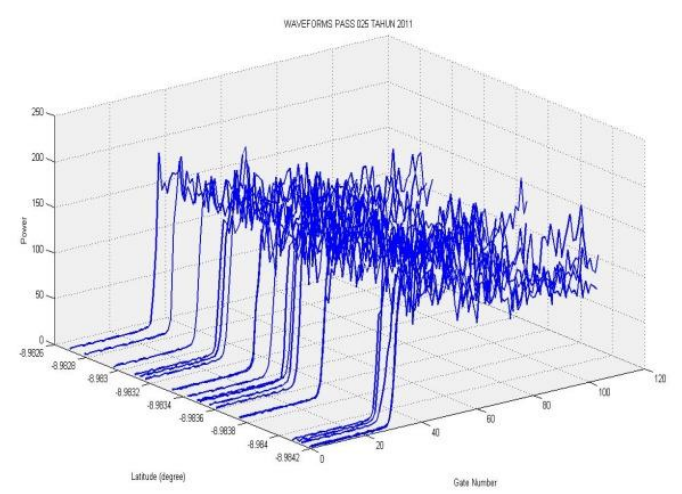

Gambar 5. Hasil Pengeplotan Waveforms Tiga Dimensi Pass 025 Tahun 2011 Menggunakan Matlab

Pada Gambar di atas menunjukkan gambar grafik dengan model tiga dimensi yang terdiri dari Gate Number, Waveforms Power, dan Latitude (lintang). Rentang lintang pada grafik disesuaikan dengan koordinat pada lokasi penelitian pada tiap 
pass. Jarak yang diambil kurang lebih $10 \mathrm{Km}$ dari pesisir pantai pada masing-masing pass.

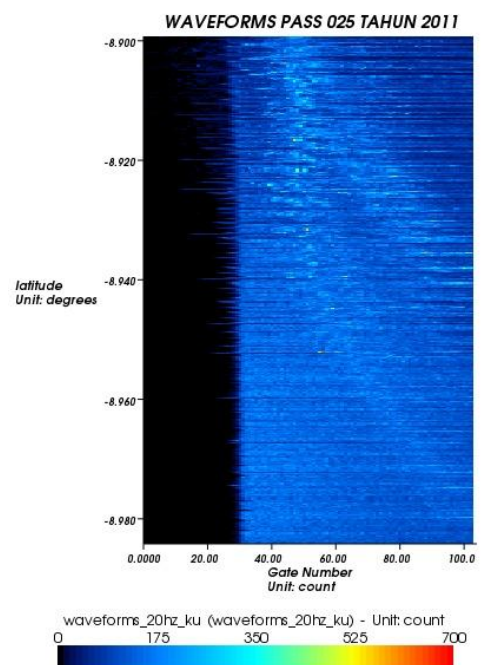

Gambar 6. Hasil Pengeplotan Waveforms Dua Dimensi Pass 025 Tahun 2011 Menggunakan BRAT

Pada Gambar di atas menunjukkan visualisasi waveforms dalam bentuk dua dimensi yang terdiri dari Latitude (lintang) dan Gate Number, sedangkan untuk Waveforms Power digambarkan pada bar berwarna yang berada dibawah gambar visualisasi tersebut.

Dengan demikian didapat hasil grafik yang sama tetapi dengan visualisasi yang berbeda dan dari hasil grafik diatas dihasilkan nilai power waveforms yang berbeda pada masing - masing pass, hal ini dikarenakan karakteristik waveforms yang berbeda pada setiap pesisir pantai yang digunakan untuk lokasi penelitian tersebut.

\section{b. Nilai COG (Centre of Gravity) Waveforms}

Perhitungan nilai COG ini dilakukan di Matlab dari data SGDR tiap cycle selama tahun 2011, dengan mengetahui nilai COG maka dapat diperoleh nilai range (a) di tiap cycle untuk perhitungan SLA pada tahapan selanjutnya. Berikut adalah tabel nilai COG dan range salah satu pass di tahun 2011 :

\begin{tabular}{|c|c|c|c|c|c|c|c|}
\hline No & Data Percycle & $\mathrm{A}(\mathrm{cm})$ & $\mathrm{W}(\mathrm{cm})$ & $\operatorname{COG}(\mathrm{cm})$ & $\mathrm{a}$ (range) $(\mathrm{cm})$ & $\mathrm{a}(\mathrm{cm})$ Perbulan & Bulan \\
\hline 1 & Cycle 092_216 & 9074.3000 & 104.5683 & 1402.9000 & 70.1451 & \multirow{3}{*}{69.5686} & \multirow{3}{*}{ Januari } \\
\hline 2 & Cycle 093_216 & 2841.0000 & 401.6327 & 1409.9000 & 70.4955 & & \\
\hline 3 & Cycle 094_216 & 3226.6000 & 440.8930 & 1361.3000 & 68.0651 & & \\
\hline 4 & Cycle 095_216 & 3081.3000 & 588.6343 & 1364.5000 & 68.2227 & \multirow{3}{*}{72.2091} & \multirow{3}{*}{ Februari } \\
\hline 5 & Cycle 096_216 & 3081.3000 & 588.6343 & 1364.5000 & 68.2227 & & \\
\hline 6 & Cycle 097_216 & 3101.9000 & 211.5615 & 1603.6000 & 80.1820 & & \\
\hline 7 & Cycle 098_216 & 2921.0000 & 248.2579 & 1593.2000 & 79.6583 & \multirow{3}{*}{76.6976} & \multirow{3}{*}{ Maret } \\
\hline 8 & Cycle 099_216 & 3121.6000 & 277.4808 & 1485.2000 & 74.2585 & & \\
\hline 9 & Cycle 100_216 & 2652.0000 & 410.4551 & \begin{tabular}{|l|l|}
1523.5000 \\
\end{tabular} & 76.1760 & & \\
\hline 10 & Cycle 101_216 & 4805.8000 & 342.5424 & 1255.9000 & 62.7940 & \multirow{3}{*}{62.3053} & \multirow{3}{*}{ April } \\
\hline 11 & Cycle 102_216 & 2795.5000 & 444.1165 & 1354.4000 & 67.7222 & & \\
\hline 12 & Cycle $103 \_216$ & 3317.2000 & 311.3606 & 1128.0000 & 56.3998 & & \\
\hline 13 & Cycle 104_216 & 8293.8000 & 269.6452 & 1471.6000 & 73.5794 & \multirow{3}{*}{56.9253} & \multirow{3}{*}{ Mei } \\
\hline 14 & Cycle $105 \_216$ & 4270.3000 & 430.8968 & 1009.4000 & 50.4698 & & \\
\hline 15 & Cycle $106 \_216$ & 4082.5000 & 429.9558 & \begin{tabular}{|l|l|}
934.5360 \\
\end{tabular} & 46.7268 & & \\
\hline 16 & Cycle 107_216 & 4065.9000 & 330.6473 & 1043.6000 & 52.1816 & \multirow{3}{*}{55.7928} & \multirow{3}{*}{ Juni } \\
\hline 17 & Cycle 108_216 & 8240.5000 & 290.2897 & 1110.5000 & 55.5258 & & \\
\hline 18 & Cycle 109_216 & 3256.4000 & 318.0974 & 1193.4000 & 59.6710 & & \\
\hline 19 & Cycle 110_216 & 3420.4000 & 255.5045 & 1026.4000 & 51.3203 & \multirow{3}{*}{56.9402} & \multirow{3}{*}{ Juli } \\
\hline 20 & Cycle 111_216 & 7961.1000 & 284.8113 & 1379.0000 & 68.9509 & & \\
\hline 21 & Cycle 112_216 & 4470.3000 & 264.9703 & 1011.0000 & 50.5495 & & \\
\hline 22 & Cycle 113_216 & 4572.8000 & 332.1365 & \begin{tabular}{|l|l|}
1047.8000 \\
\end{tabular} & 52.3876 & \multirow{3}{*}{49.5429} & \multirow{3}{*}{ Agustus } \\
\hline 23 & Cycle 114_216 & 2989.7000 & 580.3202 & 881.6189 & 44.0809 & & \\
\hline 24 & Cycle 115_216 & 4055.2000 & 307.6652 & 1043.2000 & 52.1601 & & \\
\hline 25 & Cycle 116_216 & 5049.0000 & 270.5442 & 1020.3000 & 51.0165 & \multirow{3}{*}{48.5643} & \multirow{3}{*}{ September } \\
\hline 26 & Cycle 117_216 & 3267.1000 & 328.6121 & 972.9710 & 48.6485 & & \\
\hline 27 & Cycle 118_216 & 4903.5000 & 298.1571 & 920.5585 & 46.0279 & & \\
\hline 28 & Cycle 119_216 & 4692.5000 & 329.7530 & \begin{tabular}{|l|}
1026.1000 \\
\end{tabular} & 51.3060 & \multirow{3}{*}{55.0425} & \multirow{3}{*}{ Oktober } \\
\hline 29 & Cycle $120 \_216$ & 3738.8000 & 486.4107 & 1039.4000 & 51.9708 & & \\
\hline 30 & Cycle 121_216 & 2332.8000 & 342.0393 & 1237.0000 & 61.8508 & & \\
\hline 31 & Cycle 122_216 & 4164.4000 & 324.0753 & 935.0263 & 46.7513 & \multirow{3}{*}{51.8555} & \multirow{3}{*}{ November } \\
\hline 32 & Cycle $123 \_216$ & 3541.6000 & 329.7896 & \begin{tabular}{ll|}
990.5469 \\
\end{tabular} & 49.5273 & & \\
\hline 33 & Cycle 124_216 & 15334.0000 & 61.5631 & 1185.8000 & 59.2880 & & \\
\hline 34 & Cycle $125 \_216$ & 14613.0000 & 66.9824 & 901.0924 & 45.0546 & \multirow{4}{*}{51.6559} & \multirow{4}{*}{ Desember } \\
\hline 35 & Cycle $126 \_216$ & 3123.7000 & 337.6099 & 1360.2000 & 68.0083 & & \\
\hline 36 & Cycle 127_216 & 15064.0000 & 47.6376 & 925.9675 & 46.2984 & & \\
\hline 37 & Cycle $128 \_216$ & 13067.0000 & 54.5977 & 945.2425 & 47.2621 & & \\
\hline
\end{tabular}

Gambar 7. Nilai COG Waveforms Tahun 2011 Pass 216

Berdasarkan gambar di atas, terdiri dari nilai $A$ (amplitudo), W (panjang waveforms), COG (Centre of Gravity), dan a (range). Range yang diperoleh dari hasil perhitungan tiap cycle di rata - rata untuk mendapatkan nilai range perbulan, dalam satu bulan kurang lebih terdiri dari tiga cycle karena satu cycle merupakan data hasil pengukuran selama sepuluh hari. Dan selama satu tahun kurang lebih terdiri dari 37 cycle, di tahun 2011 dimulai pada cycle 92 sampai cycle 128.

\section{c. Pengamatan Sea Level Anomaly Tahun 2011}

Pengamatan Sea Level Anomaly dilakukan dengan menggunakan dua data, yaitu data SGDR Jason-2 dengan melalui proses retracking waveforms dan data GDR Jason-2 tanpa melalui retracking. Hal ini dilakukan untuk membandingkan hasil grafik SLA dengan melalui proses retracking dan grafik SLA tanpa melalui retracking di wilayah dan waktu yang sama.

Pengamatan dilakukan tiap bulan selama tahun 2011, dari ketiga pass yang melewati wilayah pesisir Pulau Bali. 


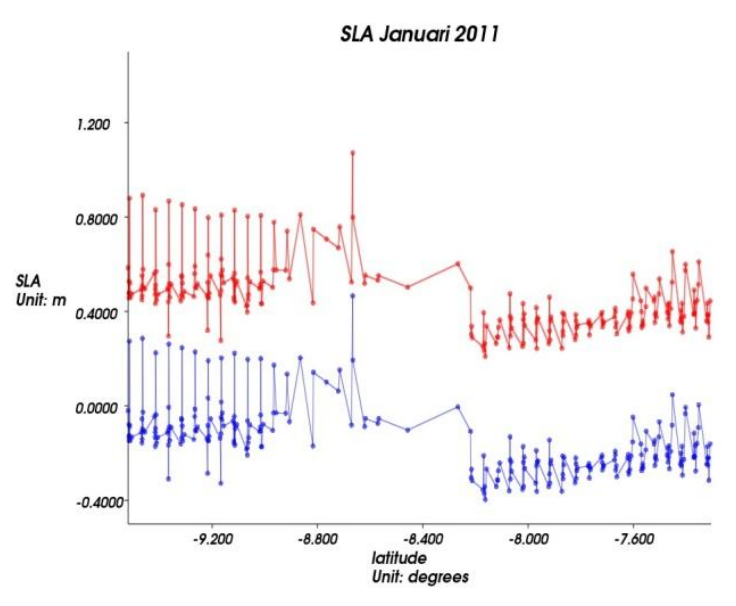

Keterangan :

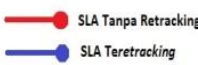

Gambar 8. Grafik SLA Wilayah Pesisir Pulau Bali pada Bulan Januari 2011

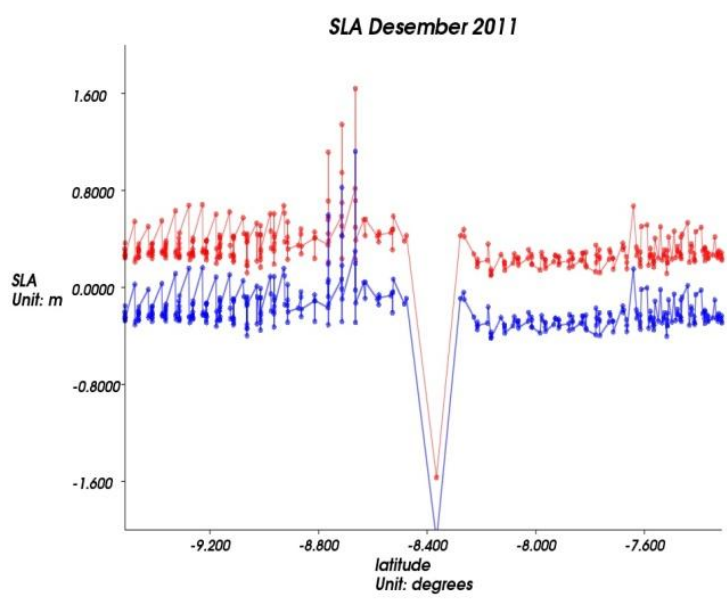

Keterangan :

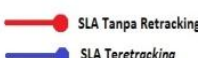

Gambar 9. Grafik SLA Wilayah Pesisir Pulau Bali pada Bulan Desember 2011

Berdasarkan grafik SLA di atas warna grafik membedakan antara data yang melalui proses retracking waveforms yaitu berwarna biru dan data tanpa melalui proses retracking waveforms yaitu berwarna merah, dan jelas mengalami perbedaan nilai SLA dari kedua hasil grafik tersebut meskipun dalam waktu dan lokasi (lintang) yang sama.

\section{d. Analisa SLA Tanpa Retracking dan SLA Teretracking}

Analisa SLA pesisir Pulau Bali dilakukan pada setiap bulan selama tahun 2011 dan secara keseluruhan selama tahun 2011. Analisa ini diperlukan untuk mengetahui nilai SLA terendah dan tertinggi pada setiap bulannya dan juga membandingkan antara hasil nilai SLA tanpa proses retracking dengan hasil nilai SLA dengan proses retracking.

\begin{tabular}{|c|c|c|c|c|c|}
\hline \multirow{2}{*}{ No } & \multirow{2}{*}{ Bulan } & \multicolumn{4}{|c|}{ Sea Level Anomaly (meter) } \\
\cline { 3 - 6 } & & \multicolumn{2}{|c|}{ SLA Tanpa Raracking } & \multicolumn{2}{|c|}{ SLA Teretracking } \\
\cline { 3 - 6 } & & Min & Max & Min & Max \\
\hline 1 & Januari & 0.2090 & 1.0729 & -0.3978 & 0.4661 \\
\hline 2 & Februari & 0.1920 & 1.5694 & -0.4607 & 0.9167 \\
\hline 3 & Maret & 0.0779 & 1.1113 & -0.5881 & 0.4453 \\
\hline 4 & Apri1 & 0.0609 & 1.5723 & -0.5563 & 0.9551 \\
\hline 5 & Mei & 0.0502 & 0.6726 & -0.4928 & 0.1296 \\
\hline 6 & Juni & -0.0816 & 1.0737 & -0.6128 & 0.5425 \\
\hline 7 & Juli & 0.0160 & 1.0093 & -0.4762 & 0.5171 \\
\hline 8 & Agustus & -0.2261 & 0.9582 & -0.7109 & 0.4734 \\
\hline 9 & September & -0.2524 & 1.1902 & -0.7607 & 0.6819 \\
\hline 10 & Oltober & -0.1522 & 1.2114 & -0.6532 & 0.7104 \\
\hline 11 & November & -15690 & 0.9979 & -2.0412 & 0.5257 \\
\hline 12 & Desember & 18690 & 1.6436 & -20984 & 1.1242 \\
\hline
\end{tabular}

Keterangan :

SLA terendah

SLA tertinggi

\section{Gambar 10. Nilai SLA Tanpa Retracking dan SLA} Teretracking Tahun 2011

Berdasarkan gambar di atas, pada tahun 2011, nilai SLA tanpa proses retracking waveforms, nilai terendah terjadi pada bulan November dan Desember yang mempunyai nilai yang sama yaitu $-1.5690 \mathrm{~m}$ dan nilai tertinggi pada bulan Desember yaitu $1.6436 \mathrm{~m}$. Untuk hasil SLA dengan proses retracking waveforms, nilai terendah terjadi pada bulan Desember yaitu $-2.0084 \mathrm{~m}$, nilai tertinggi terjadi pada bulan yang sama yaitu sebesar $1.1242 \mathrm{~m}$. 
Dan berdasarkan hasil tersebut, nilai-nilai SLA teretracking lebih rendah dibandingkan nilai - nilai SLA tanpa retracking yang hasilnya lebih tinggi dan terjadi pada setiap bulannya, nilai tertinggi SLA pada kedua proses tersebut yaitu $1.6436 \mathrm{~m}$ untuk SLA tanpa retracking dan 1.1242 m untuk SLA teretracking juga menunjukkan nilai yang lebih rendah untuk SLA teretracking.

\begin{tabular}{|c|c|c|}
\hline No & Bulan & $\begin{array}{c}\text { Selisih Nilai SLA Tanpa Retracking } \\
\text { dan SLA Teretracking (meter) }\end{array}$ \\
\hline 1 & Januari & 0.6068 \\
\hline 2 & Februari & 0.6527 \\
\hline 3 & Maret & 0.6660 \\
\hline 4 & April & 0.6172 \\
\hline 5 & Mei & 0.5430 \\
\hline 6 & Juni & 0.5312 \\
\hline 7 & Juli & 0.4922 \\
\hline 8 & Agustus & 0.4848 \\
\hline 9 & September & 0.5083 \\
\hline 10 & Oktober & 0.5010 \\
\hline 11 & November & 0.4722 \\
\hline 12 & Desember & 0.5194 \\
\hline
\end{tabular}

Gambar 11. Selisih Nilai SLA Tanpa Retracking dan SLA Teretracking

Berdasarkan gambar di atas nilai selisih tertinggi terjadi pada bulan Maret yaitu $0.6660 \mathrm{~m}$, bisa dikatakan hampir mencapai satu meter dari nilai SLA yang dihasilkan dari proses retracking waveforms yang nilainya lebih rendah dari nilai SLA yang dihasilkan tanpa retracking terlebih dahulu.

Hal ini dikarenakan dengan proses melalui retracking waveforms didapatkan nilai SLA yang lebih teliti dan baik dibandingkan tanpa melalui proses retracking terlebih dahulu, ini disebabkan satelit altimetri memiliki ketelitian yang baik di lautan lepas akan tetapi untuk mengetahui SLA pada daerah pesisir akan mengalami gangguan dalam penerimaan gelombang di akibatkan oleh ombak, vegetasi dan bentuk pesisir pantai tersebut. Maka dengan melakukan retracking waveforms terlebih dahulu akan didapatkan hasil yang lebih akurat dan lebih baik seperti pada nilai yang ditunjukkan pada tabel tersebut dan terlihat secara jelas seperti pada gambar grafik SLA yang menunjukkan nilai SLA yang tidak terlalu tinggi yang ditunjukkan grafik berwarna biru.

\section{KESIMPULAN dan SARAN}

\section{Kesimpulan}

Kesimpulan yang dapat diperoleh dari tugas akhir ini antara lain adalah sebagai berikut:

1. Hasil proses retracking waveforms di wilayah pesisir Pulau Bali dengan koordinat $7^{\circ} 18^{\prime} 18.92^{\prime \prime}$ - 9 ${ }^{\circ} 31^{\prime} 8.89^{\prime \prime} \mathrm{LS}$ dan $113^{\circ} 25^{\prime} 55.48^{\prime \prime}$ - 116 39'55.13"BT didapatkan nilai SLA tertinggi pada tahun 2011 adalah $1.1242 \mathrm{~m}$ yaitu pada bulan Desember dan nilai SLA terendahnya adalah $-2.0084 \mathrm{~m}$ pada bulan yang sama.

2. Hasil tanpa proses retracking waveforms di wilayah pesisir Pulau Bali dengan koordinat $7^{\circ} 18^{\prime} 18.92^{\prime \prime}$ - 9 $31^{\prime} 8.89^{\prime \prime}$ LS dan $113^{\circ} 25^{\prime} 55.48^{\prime \prime}$ - 116 39'55.13"BT didapatkan nilai SLA tertinggi pada tahun 2011 adalah $1.6436 \mathrm{~m}$ yaitu pada bulan Desember dan nilai SLA terendahnya adalah $-1.5690 \mathrm{~m}$ pada bulan November dan Desember.

3. Hasil plotting waveforms menggunakan Matlab dan BRAT mempermudah dalam mengetahui bentuk dan visualisasi waveforms yang terjadi pada pesisir pantai pada lokasi penelitian.

4. Nilai SLA yang dihasilkan dari proses retracking waveforms nilainya lebih rendah dari nilai SLA yang dihasilkan tanpa retracking waveforms, hal ini dikarenakan dengan proses melalui retracking waveforms didapatkan nilai SLA yang lebih teliti dan baik dibandingkan tanpa melalui proses retracking waveforms terlebih dahulu.

\section{Saran}

Saran yang dapat diberikan untuk pengembangan tugas akhir ini antara lain adalah sebagai berikut :

1. Perlunya diadakan penelitian lebih lanjut mengenai perubahan SLA (Sea Level Anomaly) di wilayah perairan Indonesia dari satelit altimetri yang terbaru mengingat hampir sebagian populasi penduduk Indonesia tersebar di wilayah pesisir.

2. Diperlukan suatu data multi satelit (3 satelit) untuk mengetahui hasil yang lebih valid.

3. Meningkatkan beberapa obyek wisata di Kabupaten Tulungagung untuk menjadi andalan tujuan wisata minimal dalam lingkup Jawa Timur. 


\section{DAFTAR PUSTAKA}

Abidin, H.Z. 2001. Geodesi Satelit. Jakarta: Pradnya Paramita.

Arief, A.R. 2009. Pemodelan Topografi Muka Air Laut (Sea Surface Topography) Dengan Menggunakan Data Satelit Altimetri Topex/Poseidon; Studi Kasus Samudera Indonesia. Surabaya : Tugas Akhir Prodi Teknik Geomatika-ITS.

AVISO. 1996. Aviso User Handbook Merged Topex/Poseidon Products (GDR-Ms). NASA dan CNES.

AVISO dan PODAAC. 2008. User Handbook IGDR and GDR Products edition 2.0. NASA dan CNES.

Away, G.A. 2006. The Shortcut of Matlab Programming. Jakarta : Penerbit Informatika.

Bao, L., Lu, Y. and Wang, Y. 2009. "Improved retracking algorithm for oceanic altimeter waveforms." Progress in Natural Science 19, no. 2: 195-203.

Deng, X., Featherstone, W. E., Hwang, C. and Berry, P .A. M. 2002. "Estimation of Contamination of ERS2 and POSEIDON Satellite Radar Altimetry Close to the Coasts of Australia." Marine Geodesy, 25:249271.
Deng, X., Lee Hyongki and Shum CK ., Roesler Caroly and E, William. 2005. "Retracking Of Radar Altimetri For Coastal Altimetri Application". Australia : The University of Newcastle.

ESA dan CNES. 2009. Basic Radar Altimetry Toolbox v2.0 User Manual.

Gunadi. 1999. Pemrosesan Topografi Muka Air Laut Dari Data Satelit Altimetri TOPEX/Poseidon. Bandung: Jurusan Teknik Geodesi Fakultas Teknik Sipil dan Perencanaan-ITB.

Handoko, E.Y. 2004. Satelit Altimetri dan Aplikasinya dalam Bidang Kelautan. Pertemuan IImiah Tahunan (PIT) 1. Surabaya: Teknik Geodesi ITS.

Raharjanto, L. 2012. Studi Pasang Surut di Perairan Indonesia dengan Menggunakan Data Satelit Altimetri Jason-1. Surabaya : Tugas Akhir Prodi Teknik Geomatika-ITS.

Sandwell, D., and W. Smith., 2009. "Global Marine Gravity From Retracked Geosat and ERS-1 Altimetry: Ridge segmentation versus spreading rate." J. geophys. Res., 114.

Sandwell, D.T. and W. Smith., July. 2005. "Retracking ERS-1 Altimeter Waveforms for Optimal Gravity Field Recovery." J. geophys. Int., 163, 79-78.

Vignudelli, S, dkk(Eds). 2011. Coastal Altimetry. Springer. 